\title{
Influence of Stakeholder Empowerment on Mobilization of Resources for Science Activities in Early Years' Education Programmes in Kisumu West Sub-County, Kenya
}

\author{
Ouko Nancy Grace ${ }^{1}$, Abuya Isaac Odhiambo ${ }^{2 *}$, Odundo Paul Amolo ${ }^{1}$ \\ ${ }^{1}$ Department of Communication \& Technology, University of Nairobi, University Way, Nairobi, Kenya \\ ${ }^{2}$ Department of Open Learning Programmes, University of Nairobi, University Way, Nairobi, Kenya
}

DOI: $10.36348 /$ jaep.2020.v04i02.001

| Received: 04.02 .2020 | Accepted: 11.02.2020 | Published: 12.02 .2020

*Corresponding author: Abuya Isaac Odhiambo

\section{Abstract}

Stakeholder empowerment is critical to the successful implementation of educational programmes. Empowered stakeholders may get actively involved in the activities of the projects, may be more willing to support decisions that may support the goals and objectives and are more likely to provide creative and innovative solutions to programme implementation challenges. Moreover, stakeholders who feel empowered may be more inclined to support both short and long term strategies of the programme. The context of early years' education programmes require more empowered stakeholders capable of making decisions on the resource needs of early years' education programmes, but have the capacity to creatively innovate and provide long term strategic thinking and networking for mobilizing teaching and learning resources for the early years' education programmes. The involvement and participation of empowered stakeholders is critically required in early years' education programmes to address the challenges of teaching and learning resources for science activities in early years' education programmes. While empirical studies suggest a relationship between stakeholder empowerment and mobilization of resources, few studies have examined the influence of stakeholder empowerment on implementation of science activities in early years' education programmes in Kisumu East Sub-County, Kenya. The study adopted cross-sectional design. The target population for the study was 1227respondents, composed of County Executive committee members, County Chief Officers, Departmental directors, Project management committee members, Sub-County Administrators, Ward administrators, EYE coordinators and EYE instructors. Simple stratified random sampling was used. Using Krecjie and Morgan table of sample estimation, a sample size of 297 was found to be sufficient for the study. Descriptive and inferential data were analysed using SPSS computer package version 21. Descriptive statistics included frequencies, percentages, means and standard deviations. Inferential statistics included correlation and regression analyses. Pearson correlation(r) and coefficients of determination $\left(\mathrm{R}^{2}\right)$, were computed to assess the association between stakeholder empowerment and resources mobilization for science activities in early years' education programme. There was significant positive association between stakeholder empowerment and resources mobilization for science activities in early years' education programme $(r=0.462 \quad \mathrm{P}<0.01)$. The study recommends that the county governments in Kenya should strengthen stakeholder empowerment strategies in their early years' education programmes to ensure sustainable resources for early years' science activities. It is also recommended that stakeholder empowerment strategies should be integrated in the design and implementation of the early years' education programmes in devolved early years' education programme in Kenya.

Keywords: Stakeholder Empowerment, Science Activities, Resources Mobilization, Early years education programmes.

Copyright @ 2020: This is an open-access article distributed under the terms of the Creative Commons Attribution license which permits unrestricted use, distribution, and reproduction in any medium for non-commercial use (NonCommercial, or CC-BY-NC) provided the original author and sources are credited.

\section{INTRODUCTION}

Stakeholder empowerment was operationally defined as stakeholder participation strategy that makes stakeholders feel empowered, enhances stakeholder autonomy, enhances stakeholder commitment, promotes stakeholder decision making, enhances stakeholders 'shared sense of purpose among early years' education stakeholders. A number of empirical studies suggest that stakeholder empowerment has significant positive effects on resources mobilization for educational programmes [1-3].

Resources forms the pillars of virtually all organizations. It is important that organization formulate strategies for resource mobilization, this 
should be identified in order to achieve the intended results [4]. Buechler [5] defined resource identification as the process of enumerating, enlisting and assessing the availability and utilization thereof. Education sector notwithstanding, resources aid in the effective transfer of content and particularly to early learners Karaka [6] and Fabian [7]. Cuthbert [8] highlights the importance of stakeholders in resource identification and mobilization. On the other hand, Chiter [9] is of the view that resource mobilization encompasses the process seeking new sources of resource mobilization, right and maximum use of the available resources. Studying the various structure and areas of resource mobilization is to seeking out resources that are essential and can be used to achieve one's mission and it maximum use. He further cites that resource mobilization does not only mean use of money but it extensiveness denotes that achieves the mission of the organization through the mobilization of knowledge in human, use of skills, equipment and services.

Essential science skills such as observing, classifying, and sorting begin to develop as early as infancy and advances with age $[10,11]$. Lack of needed stimuli experienced in science learning may result in a child's development not reaching its full potential [12]. Thus, science education in early childhood is of great importance to many aspects of a child's development, and should begin during the early years of schooling [13]. Importantly, quality science learning experiences provide a solid foundation for the subsequent development of scientific concepts that children will encounter throughout their academic lives [11]. Supporting children to develop scientific thinking during the early childhood years can lead to easily transfer their thinking skills to other academic domains which may support their academic achievement [14].

Preschool science is enjoying renewed attention in the United States among those concerned with prekindergarten education and with improving scientific literacy and achievement among the nation's citizens. The National Association for the Education of Young Children (NAEYC, n.d.) holds that children should be provided various opportunities and materials to learn key content and principles of science. Most U.S. states have articulated learning expectations for preschool science, either as a stand-alone area or as part of expectations for general cognition and language [15]. Curricula, policy statements, and funding commitments reflect beliefs that early exposure to science study concepts will lead to increased comfort with them later in life and that early experiences are critical both for school readiness and as foundations for future learning [16]. These ideas are attractive given well-established findings of the critical impact of early learning experiences on long-term educational and societal outcomes, especially among underserved populations [17]. Given these findings, it is reasonable to hypothesize that the provision of high-quality science learning experiences early in development will pay off with increased long-term achievement in, and student engagement with, science [18]. However, a recent large-scale study in Florida suggests, school readiness in science lags behind other domains [19].

Section 9 of the fourth schedule of the constitution of Kenya (promulgated in 2010), outlines pre-primary education, as a function of County government. County government thus has a responsibility on budgetary allocation for physical infrastructure, remuneration of ECD teachers and some materials. According to Otwoma [20], schoolcommunity partnership enables the school and the community to share the responsibility of running the schools and helping the child to achieve the aim of education without which neither the school nor the community can benefit. Moreover, participation and inclusiveness of parents, communities, private sector and other stakeholders in the development and management of basic education is a key principal of Basic Education Act, 2013 [21]. In recognition of importance of stakeholder collaboration, Kenya adopted Cost Sharing Policy in the education sector in 1988 following recommendations of Report of the Presidential Working Party on Education and Manpower Training for The Next Decade and Beyond: popularly called The Kamunge Report and Sessional Paper No. 6, where parents were to meet the cost of tuition, textbooks and activity fund.

According to Otwoma [20], school-community partnership enables the school and the community to share the responsibility of running the schools and helping the child to achieve the aim of education without which neither the school nor the community can benefit. While the County government have obligation to allocate part of their spent to pre-school learning, parent, International Aid agencies and other development partners have put so much effort in finding and supporting programmes. Despite, science learning experiences at pre-school considered to provide solid foundation for the subsequent development of scientific concepts that children will encounter throughout their academic lives [11] and the multispectral effort in science subject in preschool, average performance in science subject in Kenya Certificate of Primary Education in Kisumu West subcounty still lags behind other subjects. This presents a gap that this study seeks establish by answering the questions related to the participation of stakeholders in provision of materials for science learning at pre-school level.

Quality science learning in early years' education (EYE) experiences provide a solid foundation for the subsequent development of scientific concepts that children will encounter throughout their academic lives. Section 9 of the fourth schedule of the constitution of Kenya (promulgated in 2010), outlines 
pre-primary education, as a function of County government. County government thus has a responsibility on budgetary allocation for physical infrastructure, remuneration of EYE teachers and some materials. However, available evidence suggest that EYE centers do not have sufficient and age appropriate resources for science activities. Anecdotal evidence suggest that stakeholder collaboration may have positive effect on resource mobilization in EYE. However, few empirical studies have investigated the effects of stakeholder collaboration on resources mobilization for science activities in early years' education in a devolved system of governance like the one obtaining in Kenya.

\section{LITERATURE REVIEW Stakeholder Empowerment}

Stakeholder empowerment was operationally defined as stakeholder participation strategy that makes stakeholders feel empowered, enhances stakeholder autonomy, enhances stakeholder commitment, promotes stakeholder decision making, enhances stakeholders 'shared sense of purpose among early years' education stakeholders. A number of empirical studies suggest that stakeholder empowerment has significant positive effects on resources mobilization for educational programmes [1-3, 22].

Kamudu Applasawmy, Naugah and Maulloo [1] investigated the effects of empowering teachers on teaching of science activities the early years' education in Mauritius. A one-day workshop was conducted for early years' science activities teachers where teaching aids and freedom and autonomy was provided to the early years' science activities teachers. After the workshop, the teachers who attended were asked to rate their experience with the way the science activities workshop for the early years' teachers. Majority of the early years' science activities teachers reported that the workshop empowered them by giving the opportunity and freedom to make decisions in the way early years' science activities. Participants also reported that the workshop empowered them and enhanced their sense of commitment to supporting early years' learners in science activities. While the study by Kamudu Applasawmy et al., [1] investigated the effects of empowering teachers on teaching of science activities the early years' education, the current study investigated the effects of stakeholder empowerment on mobilizing resources for science activities in early years' education. The current study also assessed the extent to which its findings are consistent with the findings of the study by Kamudu Applasawmy et al., [1].

Danko-McGhee and Slutsky [2] assessed the effects of empowering approaches on capacity of preservice early years teachers to become comfortable with problem solving process. An experimental study designed was used to immerse teachers in problem solving in an environment where the teachers had the freedom and the autonomy needed for problem solving. The results of the study suggest that teacher empowering approaches improves problem solving among pre-service early years teachers and improved the teachers' commitment in addressing the problems of the early years' learners. While the study by DankoMcGhee and Slutsky [2], investigated the effects of empowering approaches on capacity of pre-service early years teachers to become comfortable with problem solving process, the current study investigated the effects of stakeholder empowerment on mobilizing resources for science activities in early years' education. The current study also assessed the extent to which its findings are consistent with the findings of the study by Danko-McGhee and Slutsky [2].

Thwaite [3] explored the effects of an empowering model on the management of early childhood literacy classrooms with indigenous learners in Australia. The design of the study was exploratory in nature. The target population for the study included early years' teachers working with young learners from vulnerable and disempowered settings and communities. The findings of the study suggest that empowering model improved the literacy skills of the young learners from vulnerable and disempowered learners, but also enhanced the learners' sense of belonging and the teachers' commitments and mutual support to the learners. Whereas the study by Thwaite [3] explored the effects of an empowering model on the management of early childhood literacy classrooms with indigenous learners, the current study investigated the effects of empowering approaches on capacity of pre-service early years teachers to become comfortable with problem solving process, the current study investigated the effects of stakeholder empowerment on mobilizing resources for science activities in early years' education. The current study also assessed the extent to which its findings are consistent with the findings of the study by Thwaite [3].

Whiteley, Smith and Hutchinson [22] conducted an experimental study on the effects of empowering approaches on the capacity of early years' education workers to identify and address areas of learning difficulties among pre-school children aged 3 5 years. The teachers were trained on how to screen learning difficulties in a training environment that gave the freedom and the leverage to make decisions and to consult among equals. After six months, an empowering screening tool was used to assess the effects of effects of empowering approaches on the capacity of early years' education workers to identify and address areas of learning difficulties. The study found that staff were not only positive about the screening process but felt that they had the power and the autonomy to make decisions based on the results screening and recognised the worth of early identification and intervention. 
Whereas the study by Whiteley, Smith and Hutchinson [22] investigated the effects of empowering approaches on the capacity of early years' education workers to identify and address areas of learning difficulties among pre-school children aged 3-5 years, the current study investigated the effects of empowering approaches on capacity of pre-service early years teachers to become comfortable with problem solving process, the current study investigated the effects of stakeholder empowerment on mobilizing resources for science activities in early years' education. The current study also assessed the extent to which its findings are consistent with the findings of the study by Whiteley et al., [22].

\section{Resources Mobilization for Science Activities in Early Years' Education Programmes}

Resources Mobilization for sciences activities in early years' education was defined operationally as availability of right learning and teaching resources, accessibility of learning and teaching resources, utilization of learning and teaching resources, enhanced safety of early years' classrooms, improved performance in science activities learning and teaching in early years' education. A number of empirical studies suggest that consultative stakeholder participation may have significant positive effects on resources mobilization for science activities in early years' education [23-26].

Piper, Merseth and Ngaruiya [27] investigated whether and how counties go beyond the basic provision of facilities and teachers to invest in learning materials, expand teacher professional development, and hire coaches to improve the quality of teaching. The mixed methods study was conducted in the 47 counties in Kenya and used the Tayari Model, a model for assessing the readiness of preschool children and the resources available for early years teaching and learning in Kenya. The target population were ECDE policy makers at national and county levels in Kenya. Data was collected using questionnaire and interview schedule. Data was analysed qualitatively and quantitatively. The results of the study suggest that the readiness of preschool children are affected by the limited learning resources in the ECDE learning centers, quality of teaching and learning and poor supervision in the ECDE centers in the county. The study recommended that, since ECDE is a devolved function in Kenya, county governments have to ensure sufficient learning and teaching resources and support the early years' instructors through quality supervision.

Bhengu and Svosve [28] explored how school heads enhanced resources mobilization in remote rural ECD schools through school-community partnerships in order to improve teaching and learning conditions. The multi-case study that was conducted in four remote rural early childhood development (ECD) schools located in the Chiredzi district, in Masvingo province,
Zimbabwe. Semi-structured interviews were conducted with the school heads, deputy heads and teachers in charge. Document reviews and observations were also used to augment data from interviews. Invitational leadership was used as an analytic tool for the study. The findings suggest that the school heads succeeded to some degree in bringing parents and various stakeholders to the ECD schools to deal with the challenges facing them. Various strategies were used including tapping into local knowledge to ensure that parents who could afford to pay fees managed to do so.

Narwana [29] explored the challenges that public schools in India face in resources mobilization for learning and teaching, and the extent to which community based programmes address these challenges. Data was collected using primary field survey and semi-structured interviews with different stakeholders in a village in Haryana, India. The findings of the study suggest most public schools in India are struggling with mobilizing resources for learning and teaching. Community based organizations that are responsible for supporting public schools to mobilize resources have not aligned their resources mobilization strategies with the needs of public schools. Moreover, socio-cultural issues including the rigid caste system, the divide between the rich and the poor in India, have adverse effects on stakeholder mobilization and participation, which further impede the ability of the public schools to have sustainable ways of mobilizing resources for learning and teaching. The study argues that the current idealization of community participation can be problematic if we fail to imbibe the social and local ethos of specific region.

Hue [30] investigates how fourth generation NGOs formulate and execute their communication strategies to achieve organizational goals, including how the NGOs use strategic communication to mobilize stakeholder support for resource mobilization. An indepth case study approach was used. The results of the study indicate that strategic communication with stakeholders is critical for sustainable resources mobilization. The study recommends that nonprofit organizations with limited resources for their operations should focus a lot of attention on strategic communication including targeting of critical stakeholders and organizations with the keys to unlock resources for their critical mission activities.

Wadell, Bengtson and Åberg [31] investigated the impact of customer attractiveness on supplier resource mobilization during radical changes such as bankruptcy. The study further assessed how the bankruptcy estate managed resource mobilization necessary for maintaining the bankrupt company's facility from the time of declaration of bankruptcy until the facility could be sold to a new owner, providing a detailed description of how the bankruptcy estate attracted suppliers despite the bankrupt company's 
previous losses. The findings show that attractiveness is a valid theoretical tool in order to understand resource mobilization also in situations that lack social aspects of relationships. Furthermore, the study shows that resource embeddedness and knowledge transfer affect customer attractiveness and impact supplier resource mobilization.

\section{METHODS AND MATERIALS Study Location}

The study was carried out in public early years education programmes centers in Kisumu West Sub County in Kisumu County, Kenya. Kisumu County has a geographical area of $565 \mathrm{Km}^{2}$ on land and $410 \mathrm{Km}^{2}$ under water of Lake Victoria. It lies between latitude $0,20^{\circ} \mathrm{s}$ and $0^{\circ}, 50^{\circ} \mathrm{s}$ of equator and Longitude $33^{\circ}, 20^{\circ} \mathrm{E}$ and $35^{\circ}, 20^{\circ}$ E. It borders Kisumu Central to the South; Seme to the West; Lake Victoria to the East, and Aldai Sub County to the North. Appendix V presents the map of the area. The Sub County is partly urban and rural, with a population of diverse backgrounds and tribes. This therefore makes the area suitable for a study that aims to establish the influence of SBP on provision of science materials for learners aged between 5 and 6 years old. This is due to the fact that family background contributes a lot to parental participation in the education of children, and diversity of background presents different challenges in behavior [32].

\section{Research Design}

The design of this study was cross-sectional. This design entails the collection of data in multiple cases at single point in time. The cross sectional design is fundamentally designed to study some research elements by taking a cross sectional look of at one time [33]. This study made the most use of this design as it enabled the researcher to collect data within a comparably shorter duration and in a cost saving fashion. According to Kothari [34], cross sectional design is based on observations made at one point in time. Kothari [34] posits that cross-sectional design collects data in a single point in time from a sample drawn from a cross section of the population. This design was therefore adopted because it is comparatively quicker to collect data within the constraints of time and resources. Moreover, crosssectional design was appropriate for this study as it involves gathering data or obtaining information about preference, attitudes, practices and concerns from a sample of a population at a particular time [35]. The design is therefore appropriate for the study as it allows data to be collected in a single point in early years' education centers. Cross-sectional design was also the most appropriate design for the study since the target population was diverse with individual differences, in terms of age, gender, education.

\section{Target Population}

The target population for this study was 1,221 , made up of 14 county executive committee members,
10 accounting officers, 15 departmental directors, 6 sub-county administrators, 30 ward administrators, 440 early years' education (EYE) management committee members, 700 EYE instructors and 6 EYE coordinators.

\section{Sample Size and Sampling Procedure}

Sample size is defined as the count of the individual samples or observations in any statistical setting also define sampling selection as the procedures used in selecting a population sample [33]. The sample size for this study is 297 drawn from a target population of 1,221 , made up of 14 county executive committee members, 10 accounting officers, 15 departmental directors, 6 sub-county administrators, 30 ward administrators, 440 early years' education (EYE) management committee members, 700 EYE instructors and 6 EYE coordinators. Krecjie and Morgan [36] sample estimation table has been used in determining the appropriate sample size for this study. Stratified random sampling procedure was used in this study. According to [33], stratified random sampling is a method of sampling that involves the division of the population into smaller groups called strata. Stratified random sampling or stratification, the strata are formed based on the member's shared attributes or characteristics [33]. Stratified random sampling involves dividing the entire population into homogenous groups, thereafter random samples are selected from each stratum [33]. Stratified random sampling ensures that each sub-group of a given population is adequately represented. Babbie [33] differentiated two types of stratified sampling: proportionate stratified method and disproportional stratified sampling method. In a proportionate stratified method, the sample size for each stratum is proportionate to the population size of the stratum. In a disproportionate sampling method, the size of each stratum is not proportionate to its size in the population. Proportionate stratified method was adopted in this study. The main advantage of stratified random sampling is that it captures the population characteristics in the sample [33]. This method also produces characteristics that are proportional to the overall population. This method was adopted in this study since it works well with a population with a variety of attributes.

\section{Data Collection Instruments}

A self-administered questionnaire was used to collect data. The self-administered Stakeholder Participation in Resources Mobilization for Science Activities Questionnaire has six sections. The questionnaire was used to collect quantitative data on the influence of the monitoring and evaluation approaches on Resources Mobilization for Science Activities. The Questionnaire had six sections A-F. Section A seeks information on the demographic profile of the research participants. Sections B to F of the Questionnaire has five Likert scale statements on the independent and dependent variable. Section B sought 
information on the effects of Collaborative Stakeholder Participation on the Resources Mobilization for Science Activities. Section C sought information on the effects of participative stakeholders' strategy on the resources mobilization for science activities. Section d sought information on the effects of Stakeholder empowerment on Resources Mobilization for Science Activities. Section E sought information on the effects of Consultative Stakeholder Participation on performance on resources mobilization for science activities and section f sought information on resources mobilization for science activities.

\section{Pilot Testing of Instruments}

The research instrument was pre-tested in Kisumu East Sub-County, Kisumu County. The requirement for pilot study is fundamental to ensuring the success of a study [37]. The pilot study was initiated for the purposes of conducting an assessment of the suitability or appropriateness of the research design and the questionnaire to be used. It was from the pilot testing phase that the researcher was able to gauge the depth of interviewees' understanding with regard to the questions posed in the instrument. In addition, pilot testing enabled the discovery of any inherent weaknesses in the questionnaires or the survey technique. Pre-testing was also a mean for gauging the time needed to administer the questionnaire. The pilot testing facilitated the identification of the key issues that needed to be addressed before the final study was conducted. Conventionally, it is advisable to sample $10 \%$ of the target population for the pre-test exercise [37]. Accordingly, the study pretested use 29 questionnaires. The pre-testing was administered among the members of the EYE management committees, since their principal duty is resources mobilization for early years' education centers and programmes.

\section{Validity of Instruments}

Validity refers to the degree to which evidence and theory support the interpretation of test scores entailed by use of tests [37]. Content validity of the questionnaires was determined from the reviews and feedback of the supervisors on the adequacy of the appropriateness and adequacy of the contents in the questionnaires. The supervisors are experts in questionnaire construction and have professional in determining the adequacy and appropriateness of research questionnaires. The feedback from the supervisors were taken into consideration when reviewing the questionnaire and the interview guide.

\section{Reliability of Instruments}

Reliability is the ability of a research instrument to consistently measure characteristics of interest over time [37]. Reliability of the research instruments was assured through pre-testing. The research instruments were pre-tested in Kisumu East Sub-County in Kisumu County. Kothari [37] advises that it is always advisable to conduct a pilot study. A pilot investigation was first conducted in order to assess the adequacy of the research design and of the questionnaire to be used such as to determine whether the anticipated respondents understands the questions asked in the instrument. Furthermore, a pilot survey brings to light the weaknesses of the questionnaires and of the survey techniques. Pilot testing enabled the researcher to identify issues with the questionnaires which were addressed before the final study. Pre-testing enabled the researcher to estimate the time that it would take to administer each questionnaire. Kothari also advises that $10 \%$ of the sample is sufficient for pilot testing. Based on this advice, the study pretested use 29 questionnaires. The pre-testing was administered among the members of the EYE management committees, since their principal duty is resources mobilization for early years' education centers and programmes.

\section{Data Collection Procedure}

The University of Nairobi issued the researcher with a letter clearing the researcher to obtain a research permit. After the issuance of the clearance letter from the University, an application letter for a research permit was obtained from the National Commission for Science, Technology and Innovation (NACOSTI). Once the research permit was issued, the researcher informed the County Commissioner and the Department of Basic Education at the County about the intention to carry out the research. The County Government was also informed about the purpose of the study. The researcher asked the County Secretary to inform the County Human Resource Director about the study. The Human Resource Director provided the contact of the staff to be interviewed and also informed them about the study; and asked the targeted research participants to support the study. Once the respondents were identified, their consent to participate in the study was required. The researcher also explained the purpose of the study to the respondents after seeking their consent. The questionnaires were thereafter administered and collected soon after ensuring that all the sections had been duly completed.

\section{Data Analysis Techniques}

Both descriptive and inferential analyses were conducted. Descriptive statistics included frequencies, means, standard deviations. Inferential statistics included correlation and regression analyses. The inferential statistics determine the associations or relationships between the stakeholder participation and resources mobilization for science activities. Quantitative data were entered in the Statistical Packages for Social Sciences (SPSS). Unique identifiers were given to each questionnaire before entry to assure confidentiality of the respondents. 
Ouko Nancy Grace et al; J Adv Educ Philos, Feb 2020; 4(2): 17-28

\section{Ethical Considerations of the Study}

Ethical consideration is paramount for every study. Ethical issues apply to all research approaches and to every stage of research that is, in the identification of the research problem, data collection, data analysis and interpretation, and lastly in the writing and dissemination of the research [38]. Ethical issues involved matters of access, confidentiality and anonymity of the participants, the participants' consent as well as legal issues like intellectual ownership, confidentiality, privacy, access and acceptance [39]. The researcher assured confidentiality and sought informed consent and ensured the autonomy of the research participants.

\section{RESULTS \\ Questionnaire Return Rate}

The sample size for this study was 290. However, seventeen respondents opted not to participate in the study, thereby reducing the number by research participants to 280 . The total number of questionnaires that were filled and returned were 280 . The return rate was therefore $96.5 \%$. Table-1 summarizes the questionnaire return rate.

Table-1: Questionnaire Return Rate

\begin{tabular}{|l|l|l|}
\hline Sample size & Questionnaires filled & Percent return rate (\%) \\
\hline 290 & 280 & $96.5 \%$ \\
\hline
\end{tabular}

\section{Background Information of the Research Participants}

The study sought information on demographic profiles of the research participants. Table-2 presents demographic profile data of the research participants.

Table-2: Distribution of Demographic Characteristics of Respondents

\begin{tabular}{|c|c|c|c|}
\hline & \multicolumn{3}{|l|}{ Number of respondents $\mathrm{N}=\mathbf{2 8 0}$} \\
\hline & & Frequencies & Percentage \\
\hline \multirow[t]{3}{*}{ Gender of the respondents } & Male & 113 & 40.4 \\
\hline & Female & 167 & 59.6 \\
\hline & Total & 280 & 100.0 \\
\hline \multirow[t]{8}{*}{ Age of the respondents } & $18-20$ & 5 & 1.8 \\
\hline & $21-25$ & 22 & 7.9 \\
\hline & $26-30$ & 61 & 21.8 \\
\hline & $31-35$ & 64 & 22.9 \\
\hline & $36-40$ & 59 & 21.1 \\
\hline & $41-45$ & 38 & 13.6 \\
\hline & Above 45 years & 31 & 11.1 \\
\hline & Total & 280 & 100.0 \\
\hline \multirow[t]{5}{*}{ Marital status } & Married & 187 & 66.8 \\
\hline & Widowed & 29 & 10.4 \\
\hline & Divorced & 7 & 2.5 \\
\hline & Not married & 57 & 20.4 \\
\hline & Total & 280 & 100.0 \\
\hline \multirow[t]{7}{*}{ Highest Educational Qualification } & $\mathrm{PhD}$ & 3 & 1.1 \\
\hline & Masters & 25 & 8.9 \\
\hline & Bachelor's & 44 & 15.7 \\
\hline & Diploma & 100 & 35.7 \\
\hline & Secondary school & 89 & 31.8 \\
\hline & Primary & 19 & 6.8 \\
\hline & Total & 280 & 100.0 \\
\hline \multirow[t]{9}{*}{ Position in the county } & Executive committee members & 5 & 1.8 \\
\hline & Chief officers & 6 & 2.1 \\
\hline & Directors & 12 & 4.3 \\
\hline & Sub-county administrators & 5 & 1.8 \\
\hline & Ward administrators & 23 & 8.2 \\
\hline & Project managements committee member & 101 & 36.1 \\
\hline & ECDE coordinators & 7 & 2.5 \\
\hline & ECDE Instructor(teacher) & 121 & 43.2 \\
\hline & Total & 280 & 100.0 \\
\hline
\end{tabular}


Table-2 presents the distribution of demographic characteristics of respondents. The demographic questionnaire for stakeholder participation in resource mobilization for science activities in early years' education sought information on gender of the respondents, their age bracket, marital status, highest educational qualification and position held in the County. Out of the 280 respondents, 167(59.6\%) were female and $113(40.4 \%$ ) were male suggesting that majority of those interviewed were female. It is also an indication that county government of Siaya the government has embraced gender equity and women empowerment. On the age bracket findings, majority of the respondents who filled in the questionnaire were 64(22.9\%) aged between 31-35years; 61(21.8\%) aged between 26-30years; $59(21.1 \%)$ aged between 36-40 years; 38(13.6\%) aged between 41-45years; 31(11.1\%) aged above 45 years; $22(7.9 \%)$ aged between 21-25 years and $5(1.8 \%)$ aged between $18-20$ years. The findings on marital status suggested that out of 280 respondents, majority $187(66.8 \%)$ were married, $57(20.4 \%)$ were not married, $29(10.4 \%)$ were widowed and $7(2.5 \%)$ were divorced. Findings on highest educational qualification indicated that $100(35.7 \%)$ were diploma holders, $89(31.8 \%)$ secondary school, $44(15.7 \%)$ degree holders, 25(8.9\%) masters and $3(1.1 \%) \mathrm{PhD}$ holders. This indicates the county has embraced formal education as the figures shows relatively high literacy level among the respondents. Lastly on the demographic characteristics, findings revealed that out of the 280 respondents, 121(43.2\%) were ECDE instructors, 101(36.1\%) were Project management committee members, 23(8.2\%) were ward administrators, $12(4.3 \%)$ directors, $6(2.1 \%)$ Chief officers, $5(1.8 \%)$ county executive and $5(1.8 \%)$ subcounty administrators.

\section{Descriptive Analysis of Resource Mobilization for Science Activities Programmes}

The dependent variable for this study was resource mobilization for science activities. To measure research participants' perspectives on resource mobilization for science activities, five statements on the indicators were developed in the self-administered questionnaire using a five likert scale.

Table-3: Descriptive Statistics of Resource Mobilization for Science Activities Programmes

\begin{tabular}{|l|l|l|l|l|l|l|l|}
\hline Statement & SD & D & N & A & SA & Mean & SD \\
\hline $\begin{array}{l}\text { SPRMSA 1-Stakeholder participation } \\
\text { ensures availability of right science } \\
\text { activities learning and teaching resources }\end{array}$ & $26(9.3 \%)$ & $65(23.2 \%)$ & $69(24.6 \%)$ & $73(26.1 \%)$ & $47(16.8 \%)$ & 3.1786 & 1.22850 \\
\hline $\begin{array}{l}\text { SPRMSA 2-Stakeholder participation } \\
\text { improves accessibility of science } \\
\text { activities learning and teaching resources }\end{array}$ & $21(7.5 \%)$ & $69(24.6 \%)$ & $81(28.9 \%)$ & $72(25.7 \%)$ & $37(13.2 \%)$ & 3.1250 & 1.14945 \\
\hline $\begin{array}{l}\text { SPRMSA 3-Stakeholder participation } \\
\text { enhances utilization of science activities } \\
\text { learning and teaching resources }\end{array}$ & $10(3.6 \%)$ & $36(12.9 \%)$ & $99(35.4 \%)$ & $95(33.9 \%)$ & $40(14.3 \%)$ & 3.4250 & 1.00255 \\
\hline $\begin{array}{l}\text { SPRMSA 4-Stakeholder participation } \\
\text { enhances safety of early years' education } \\
\text { science activities classrooms }\end{array}$ & $6(2.1 \%)$ & $25(8.9 \%)$ & $91(32.5 \%)$ & $111(39.6 \%)$ & $47(16.8 \%)$ & 3.6000 & 0.94129 \\
\hline $\begin{array}{l}\text { SPRMSA 5-Stakeholder participation } \\
\text { improves performance in science } \\
\text { activities learning and teaching. }\end{array}$ & $14(5.0 \%)$ & $32(11.4 \%)$ & $73(26.1 \%)$ & $118(42.1 \%)$ & $43(15.4 \%)$ & 3.5143 & 1.04374 \\
\hline
\end{tabular}

Table-3 presents the descriptive statistics on the perspective of the research participants on stakeholders' participation on resource mobilization for science activities. Item SPRMSA 1 sought to establish to what extent SPRMSA 1-Stakeholder participation ensures availability of right science activities learning and teaching resources. Out 280 respondents who responded to the item, $73(26.1 \%)$ agreed, 69(24.6\%) were neutral, $65(23.2 \%)$ disagreed with the statement, $47(16.8 \%)$ strongly agreed and 26(9.3\%) strongly disagreed. The mean for item SPRMSA 1 was 3.1786 and the standard deviation was 1.22850, suggesting that majority of the respondents agreed that stakeholder participation ensures availability of right science activities learning and teaching resources.

Item SPRMSA 2 sought to establish to what extent stakeholder participation improves accessibility of science activities learning and teaching resources.
Out 280 respondents who responded to the item, $81(28.9 \%)$ were neutral, $72(25.7 \%)$ agreed with the statement, $69(24.6 \%)$ disagreed, $37(13.2 \%)$ strongly agreed and 21(7.5\%) strongly disagreed. The mean for item SPRMSA 2 was 3.1250 and the standard deviation was 1.14945, suggesting that majority of the respondents agreed that stakeholder participation improves accessibility of science activities learning and teaching resources.

Item SPRMSA 3 sought to establish to what extent stakeholder participation enhances utilization of science activities learning and teaching resources. Out 280 respondents who responded to the item, 99(35.4\%) were neutral, 95(33.9\%) agreed, 40(14.3\%) strongly agreed with the statement, $36(12.9 \%)$ disagreed and $10(3.6 \%)$ strongly disagreed. The mean for item SPRMSA 3 was 3.4250 and the standard deviation was 1.00255 , suggesting that majority of the respondents 
gave a neutral response that stakeholder participation enhances utilization of science activities learning and teaching resources.

Item SPRMSA 4 sought to establish to what extent stakeholder participation enhances safety of early years' education science activities classrooms. Out 280 respondents who responded to the item, 111(39.6\%) agreed, 91(32.5\%) were neutral, 47(16.8\%) strongly agreed with the statement, 25(8.9\%) disagreed and $6(2.1 \%)$ strongly disagreed. The mean for item SPRMSA 4 was 3.6000 and the standard deviation was 0.94129 , suggesting that majority of the respondents agreed that stakeholder participation enhances safety of early years' education science activities classrooms.

Item SPRMSA 5 sought to establish to what extent stakeholder participation improves performance in science activities learning and teaching. Out 280 respondents who responded to the item, 118(42.1\%) agreed, $73(26.1 \%)$ neutral, 43(15.4\%) strongly agreed with the statement, 32(11.4\%) disagreed, and 14(5.0\%) strongly disagreed. The mean for item SPRMSA 5 was 3.5143 and the standard deviation was 1.04374, suggesting that majority of the respondents agreed that stakeholder participation improves performance in science activities learning and teaching.

\section{Descriptive Analysis of Stakeholder empowerment on Resource Mobilization for Science Activities in Early years education programmes}

The study sought to establish the frequencies, percentages, means and standard deviation on the Stakeholder empowerment.

Table-4: Descriptive Statistics on Stakeholder empowerment and Resource Mobilization for Science Activities in Early Years' Education Programmes

\begin{tabular}{|c|c|c|c|c|c|c|c|}
\hline Statement & SD & D & $\mathbf{N}$ & $\mathbf{A}$ & $\mathbf{S A}$ & Mean & Sd \\
\hline $\begin{array}{l}\text { ESP1- Empowering resource } \\
\text { mobilization makes early years' } \\
\text { education stakeholders to feel } \\
\text { empowered. }\end{array}$ & $10(3.6 \%)$ & $13(4.6 \%)$ & $22(7.9 \%)$ & $108(38.6 \%)$ & $127(45.4 \%)$ & 4.1750 & 1.00612 \\
\hline $\begin{array}{lrr}\text { ESP2- } & \text { Empowering } & \text { resource } \\
\text { mobilization enhances } & \text { autonomy } \\
\text { among early years' } & \text { education } \\
\text { stakeholders } & & \\
\end{array}$ & $6(2.1 \%)$ & $18(6.4 \%)$ & $39(13.9 \%)$ & $116(41.4 \%)$ & $101(36.1 \%)$ & 4.0286 & 0.97601 \\
\hline $\begin{array}{l}\text { ESP3- Empowering resource } \\
\text { mobilization enhances a sense of } \\
\text { commitment among early years' } \\
\text { education stakeholders }\end{array}$ & $5(1.8 \%)$ & $15(5.4 \%)$ & $39(13.9 \%)$ & $118(42.1 \%)$ & $103(36.8 \%)$ & 4.0679 & 0.93845 \\
\hline $\begin{array}{l}\text { ESP4- Empowering resource } \\
\text { mobilization promotes decision } \\
\text { making ability among early years'. }\end{array}$ & $12(4.3 \%)$ & $31(11.1 \%)$ & $70(25.0 \%)$ & $114(40.7 \%)$ & $53(18.9 \%)$ & 3.5893 & 1.05029 \\
\hline $\begin{array}{l}\text { ESP5- Empowering resource } \\
\text { mobilization enhances a shared } \\
\text { sense of purpose among early years' } \\
\text { education stakeholders }\end{array}$ & $6(2.1 \%)$ & $17(6.1 \%)$ & $26(9.3 \%)$ & $112(40.0 \%)$ & $119(42.5 \%)$ & 4.1462 & 0.96720 \\
\hline
\end{tabular}

Table-4 presents the descriptive statistics on the perspective of the research participants on the stakeholder empowerment and resource mobilization for science activities in early years' education.

Item ESP1 sought to establish to what extent empowering resource mobilization makes early years' education stakeholders to feel empowered. Out 280 respondents who responded to the item, 127(45.4\%) strongly agreed, 108(38.6\%) agreed with the statement, $22(7.9 \%)$ were neutral, 13(4.6\%) and 10(3.6\%) strongly disagreed. The mean for item ESP1 was 4.1750 and the standard deviation was 1.00612, suggesting that majority of the respondents strongly agreed that Empowering resource mobilization makes early years' education stakeholders to feel empowered.

Item ESP2 sought to establish to what extent empowering resource mobilization enhances autonomy among early years' education stakeholders. Out 280 respondents who responded to the item, 116(41.4\%) agreed, 101(36.1\%) strongly agreed with the statement,
$39(13.9 \%)$ were neutral, $18(6.4 \%)$ disagreed and $6(2.1 \%)$ strongly disagreed. The mean for item ESP2 was 4.0286 and the standard deviation was 0.97601 , suggesting that majority of the respondents agreed that empowering resource mobilization enhances autonomy among early years' education stakeholders.

Item ESP3 sought to establish to what extent empowering resource mobilization enhances a sense of commitment among early years' education stakeholders. Out 280 respondents who responded to the item, $118(42.1 \%)$ agreed, $103(36.8 \%)$ strongly agreed with the statement, 39(13.9\%) were neutral, $15(5.4 \%)$ disagreed and 5(1.8\%) strongly disagreed. The mean for item ESP3 was 4.0679 and the standard deviation was 0.93845 , suggesting that majority of the respondents agreed that empowering resource mobilization enhances a sense of commitment among early years' education stakeholders. 
Item ESP4 sought to establish to what extent that empowering resource mobilization promotes decision making ability among early years' education stakeholders. Out 280 respondents who responded to the item, 114(40.7\%) agreed, 70(25.0\%) neutral, $53(18.9 \%)$ strongly agreed with the statement, $31(11.1 \%)$ disagreed and $12(4.3 \%)$ strongly disagreed. The mean for item ESP4 was 33.5893 and the standard deviation was 1.05029 , suggesting that majority of the respondents agreed that empowering resource mobilization promotes decision making ability among early years' education stakeholders.

Item ESP5 sought to establish to what extent empowering resource mobilization enhances a shared sense of purpose among early years' education stakeholders. Out 280 respondents who responded to the item, 119(42.5\%) strongly agreed, 112(40.0\%) agreed, 26(9.3\%) neutral, 17(6.1\%) disagreed with the statement and 6(2.1\%) strongly disagreed. The mean for item ESP5 was 4.1462 and the standard deviation was 0.96720 , suggesting that majority of the respondents strongly agreed that empowering resource mobilization enhances a shared sense of purpose among early years' education stakeholders.

\section{Correlation Analysis of Stakeholder empowerment and Resource Mobilization for Science Activities in Early Years Education Programmes}

Pearson product moment correlation coefficient was used to establish the existence or nonexistence of significant relationship as well as the degree or strength of association between stakeholder empowerment and resource mobilization for science activities in early years' education, based on the perspectives of the research participants.

Table-5: Correlation Analysis

\begin{tabular}{|l|l|l|l|}
\hline \multicolumn{2}{|c|}{} & $\begin{array}{l}\text { Stakeholder } \\
\text { empowerment }\end{array}$ & $\begin{array}{l}\text { Resource Mobilization for Science Activities } \\
\text { in Early years' education programmes }\end{array}$ \\
\hline \multirow{3}{*}{ Stakeholder empowerment } & Pearson Correlation & 1 & .462 \\
\cline { 2 - 4 } & Sig. (2-tailed) & .000 \\
\cline { 2 - 4 } & $\mathrm{N}$ & 280 & 280 \\
\hline $\begin{array}{l}\text { Resource Mobilization for } \\
\text { Science Activities in Early } \\
\text { years education programmes }\end{array}$ & Pearson Correlation & $.462^{* * *}$ & 1 \\
\cline { 2 - 4 } & Sig. (2-tailed) & .000 & 280 \\
\cline { 2 - 4 } & $\mathrm{N}$ & 280 & \\
\hline$* *$ Correlation is significant at the 0.01 level (2-tailed). & \\
\hline
\end{tabular}

Table-5 presents correlation analysis of stakeholder empowerment and resource mobilization for science activities in early years' education. The analysis shows a moderately weak correlation between variables stakeholder empowerment and resource mobilization for science activities in early years' education $(\mathrm{r}=0.462 \mathrm{P}<0.01)$. This indicates statistical significance between stakeholder empowerment and resource mobilization for science activities in early years' education. The findings are consistent with the findings of studies reviewed under the literature review that found significant relationship between stakeholder empowerment and resources mobilization for science activities in early years' education $[1-3,5]$.
Regression analysis of Stakeholder empowerment and Resource Mobilization for Science Activities in Early years' education programmes

To find the amount of variation in resource mobilization for science activities in early years' education, which explains its association with stakeholder empowerment, the coefficient of determination (R2) was computed. The coefficient was also computed to help in understanding or explaining the amount of variation in resource mobilization for science activities in early years' education.

Table-6: Model Summary of Association between Stakeholder empowerment and Resource Mobilization for Science Activities in Early Years Education Programmes

\begin{tabular}{|l|l|l|l|l|}
\hline \multicolumn{4}{|c|}{ Model Summary } \\
\hline Model & R & R Square & Adjusted R Square & Std. Error of the Estimate \\
\hline 1 & $0.462^{\mathrm{a}}$ & .213 & .211 & .89397 \\
\hline
\end{tabular}

a. Predictors: (Constant), Stakeholder empowerment.

Table-6 is the model summary of the association between stakeholder empowerment and resource mobilization for science activities in early years' education. The above model summary table indicates that there is a positive multiple correlation coefficient $(\mathrm{R}=0.462)$ between resource mobilization for science activities in early years' education and stakeholder empowerment and those predicted by the regression model. In addition, the coefficient of determination ( $R 2=21.3 \%$ ) suggests that the amount of variance in resource mobilization for science activities in early years' education is explained by stakeholder empowerment. The findings are consistent with the findings of studies reviewed under the literature review 
that found significant relationship between stakeholder empowerment and resources mobilization for science activities in early years' education [1-3, 22].

\section{DISCUSSION AND CONCLUSION}

The research objective was to determine the influence of empowering stakeholders' participation on resource mobilization for science activities in early years' education in Kisumu West Sub-County. The analysis shows a moderately weak correlation between Stakeholder empowerment and Resource Mobilization for Science Activities in Early years' education programmes $(r=0.462 \mathrm{P}<0.01)$. This indicates statistical significance between the variables. The $\mathrm{R}$-value is $0.462(4.62 \%)$ which shows moderate correlation. The R-square is $21.3 \%$ which means that combined independent variables account for $4.5 \%$ of the variation in the dependent variable. This means that there are other factors that account for $78.7 \%$.

The findings of this study will assist the county governments to formulate a more focused stakeholder participation strategy for resource mobilization for science activities early years' education and to ensure sustainable financing of teaching and learning resources in early years' education programmes. Finally, the findings of this will contribute to further research on stakeholder participation in resource mobilization for sustainable development in devolved governments in and outside Kenya. The study found statistically significant association between stakeholder empowerment strategies and resource mobilization for science activities. Based on these findings, it is recommended that the County government should strengthen its stakeholder empowerment strategies. It is also recommended that stakeholder empowerment strategies should be integrated in the design and daily implementation of the early years' education curriculum to ensure sustainable mobilization of financing of teaching and learning resources for early years' education.

\section{REFERENCE}

1. Kamudu Applasawmy, B., Naugah, J., \& Maulloo, A. K. (2017). Empowering teachers to teach science in the early years in Mauritius. Early Child Development and Care, 187(2), 261-273.

2. Danko-McGhee, K., \& Slutsky, R. (2007). Floating Experiences: Empowering Early Childhood Educators to Encourage Critical Thinking in Young Children through the Visual Arts. Art Education, 60(2), 13-16.

3. Thwaite, A. (2007). Inclusive and Empowering Discourse in an Early Childhood Literacy Classroom with Indigenous Students. Australian Journal of Indigenous Education, 36, 21-31.

4. Chisham, G., Lester, M., Milan, S. E., Freeman, M. P., Bristow, W. A., Grocott, A., ... \& Greenwald, R. A. (2007). A decade of the Super
Dual Auroral Radar Network (SuperDARN): Scientific achievements, new techniques and future directions. Surveys in geophysics, 28(1), 33109.

5. Kopp, A., Buechler, C., Neumeier, M., Weigert, J., Aslanidis, C., Schölmerich, J., \& Schäffler, A. (2009). Innate immunity and adipocyte function: ligand- specific activation of multiple Toll- like receptors modulates cytokine, adipokine, and chemokine secretion in adipocytes. Obesity, 17(4), 648-656.

6. Karaka, K. (2007). Effective teaching in school.

7. Fabian, J., Matos-Abiague, A., Ertler, C., Stano, P., \& Zutic, I. (2007). Semiconductor spintronics. arXiv preprint arXiv:0711.1461.

8. Cuthbert, A. (2011). Understanding cities: method in urban design. Routledge.

9. Chiter, A., Forbes, J. M., \& Blair, G. E. (2012). DNA stability in plant tissues: implications for the possible transfer of genes from genetically modified food. FEBS letters, 481(2), 164-168.

10. Piaget, J., \& Inhelder, B. (2000). The Psychology of the Child Tr. H. Weaver.

11. Eshach, H., \& Fried, M. N. (2005). Should science be taught in early childhood?. Journal of science education and technology, 14(3), 315-336.

12. Hadzigeorgiou, Y. (2005). Romantic understanding and science education. Teaching Education, 16(1), 23-32.

13. Watters, J. J., Diezmann, C. M., Grieshaber, S. J., \& Davis, J. M. (2001). Enhancing science education for young children: A contemporary initiative. Australasian Journal of Early Childhood, 26(2), 1-7.

14. Kuhn, D., \& Pearsall, S. (2000). Developmental origins of scientific thinking. Journal of cognition and Development, 1(1), 113-129.

15. Snow, C. E., \& Van Hemel, S. B. (2008). Early childhood assessment: Why, what, and how. The National Academies Press.

16. Beering, D. R., Tseng, S., Hayden, J. L., Corder, A., Ooi, T., Elwell, D., ... \& Johnson, A. M. (2009, October). RF communication data model for satellite networks. In MILCOM 2009-2009 IEEE Military Communications Conference (pp. 1-7). IEEE.

17. Barnett, T. P., Pierce, D. W., Hidalgo, H. G., Bonfils, C., Santer, B. D., Das, T., ... \& Cayan, D. R. (2008). Human-induced changes in the hydrology of the western United States. science, 319(5866), 1080-1083.

18. National Research Council, Donovan, S., \& Bransford, J. (2005). How students learn. National Academies Press.

19. Greenfield, D. B., Jirout, J., Dominguez, X., Greenberg, A., Maier, M., \& Fuccillo, J. (2009). Science in the preschool classroom: A programmatic research agenda to improve science readiness. Early Education and Development, 20(2), 238-264. 
20. Otwoma, A. D. (2006). Home Environment and the School in relation to Education.

21. Koei, N. (2013). The Project on the Development of the National Water Master Plan 2030; Final Report; Volume V Sectoral Report (E)Agriculture and Irrigation; The Republic of Kenya. Water Resources Management Authority: Nairobi, Kenya.

22. Whiteley, H., Smith, C., \& Hutchinson, J. (2005). Empowering early years workers to identify and target areas of difficulty in pre-school children. Early Years: Journal of International Research and Development, 25(2), 155-166.

23. Dinnebeil, L., Pretti-Frontczak, K., \& McInerney, W. (2009). A Consultative Itinerant Approach to Service Delivery: Considerations for the Early Childhood Community. Language, Speech and Hearing Services in Schools, 40(4), 435-445.

24. Case-Smith, J., \& Holland, T. (2009). Making Decisions About Service Delivery in Early Childhood Programs. Language, Speech and Hearing Services in Schools, 40(4), 416-423.

25. Frankel, R., \& Li, X. (2004). Characteristics of a firm's information environment and the information asymmetry between insiders and outsiders. Journal of Accounting and Economics, 37(2), 229-259.

26. DeVore, S., Miolo, G., \& Hader, J. (2011). Individualizing Inclusion for Preschool Children Using Collaborative Consultation. Young Exceptional Children, 14(4):31-43.

27. Piper, B., Merseth, K. A., \& Ngaruiya, S. (2018). Scaling up Early Childhood Development and Education in a Devolved Setting: Policy Making, Resource Allocations, and Impact of the Tayari School Readiness Program in Kenya. Global Education Review, 5(2):47-68.

28. Bhengu, T. T., \& Svosve, E. (2019). Transforming Education through School-Community Partnerships: Lessons from Four Rural Early
Childhood Development Schools in Zimbabwe. Africa Education Review, 16(2), 16-35.

29. Narwana, K. (2015). A Global Approach to School Education and Local Reality: A Case Study of Community Participation in Haryana, India. Policy Futures in Education, 13(2):219233.

30. Hue, D. T. (2017). Fourth Generation NGOs: Communication Strategies in Social Campaigning and Resource Mobilization. Journal of Nonprofit and Public Sector Marketing, 29(2):119-147.

31. Wadell, O., Bengtson, A., \& Åberg, S. (2019). From dusk till dawn: Attracting suppliers for resource mobilization during bankruptcy. Journal of Purchasing and Supply Management, 25(3), N.PAG.

32. Lewis, S. C. (2010). Journalism innovation and the ethic of participation: A case study of the Knight Foundation and its news challenge.

33. Maxfield, M. G., \& Babbie, E. R. (2014). Research methods for criminal justice and criminology. Cengage Learning.

34. Kothari, V., \& Antal Jr, M. J. (1985). Numerical studies of the flash pyrolysis of cellulose. Fuel, 64(11), 1487-1494.

35. MacMillan, J. H., \& Schumacher, S. (2010). Research in Education: Evidence-Based Inquiry [with my education lab].

36. Krejcie, R. V., \& Morgan, D. W. (1970). Educational and psychological measurement. New York: Minnisota University.

37. Kothari, C. R. (2004). Research methods and techniques. New Age International Publishers: New Delhi.

38. Creswell, J. (2014). Qualitative Inquiry and Research Design: Choosing Among Five Approaches-John W. Creswell, Cheryl N. Poth.

39. Johnson, M. W., Christensen, C. M., \& Kagermann, H. (2008). Reinventing your business model. Harvard business review, 86(12), 57-68. 